\title{
Effect of Brand Equity on Consumer Behaviour Among Students of Veritas University, Nigeria: A Study of Apple Smartphones
}

\author{
Michael Oyenuga $^{1^{*}}$, Agnes Ahungwa², Emmanuel Onoja ${ }^{3}$ \\ ${ }^{1,2,3}$ Department of Marketing, Veritas University, Bwari, Abuja, Nigeria
}

\section{Keywords: \\ Brand Association, Brand Awareness, Brand Loyalty, Consumer Behaviour}

\section{Received}

29 December 2020

Received in revised form

05 January 2021

Accepted

09 January 2021

*Correspondence: mentormike2000@yahoo

\begin{abstract}
The mobile phone industry is a very innovative segment within the ICT sector, and the smartphone is gradually becoming the standard configuration of mobile devices and currently represents the fastest growing market in the telecoms industry. Previous studies on brand equity tend to focus on telecommunications, banking, hospitality, banking, construction, fast-moving customer goods, etc., while ignoring the education sector. Therefore, the general objective of the study is to evaluate the brand equity of apple smartphones and customer behavior in Abuja. The study adopted a cross-sectional research design. The study used primary data through a questionnaire using 341 samples. Specifically, the objectives of the study were to establish the extent to which brand awareness, brand association, and brand loyalty affect customer behaviour among students of Veritas University. The resutls revealed that brand awareness, brand association, and brand loyalty positively and significantly affect customer behaviour among Veritas University students. It was concluded that when consumers are attached and loyal to a brand, they are likely to make repeat purchases. This only happens when the relationship between the brand and the user is very in-depth and has an emotional connection with the mobile brand. The study recommended that firms interested in extending customer behaviour to repurchase their product categories should pay special attention to brand loyalty, brand awareness, brand association linked to the functions of guarantee, social identification, and status.
\end{abstract}

(C)CIKD Publishing

The mobile phone industry is a very innovative segment within the ICT sector. The smartphone is gradually becoming the standard configuration of mobile devices and currently represents the fastest growing market in the telecoms industry (Cecere, Corrocher, \& Battaglia, 2014). Cecere et al. noted that for the first time, in 2014, sales of internet-connected smartphones exceeded those 
for more basic handsets, such that global smartphone sales grew by $3.6 \%$ to 435 billion units in the second quarter of 2013, accounting for more than half of the market. Sarwar and Soomro (2013) observed that, although smartphones have been in the market since 1993, it was not until the end of 2006 that the Blackberry was introduced into the market and that the smartphone became a commercially successful product. In 2007, Apple entered the market by developing the first iPhone model, and soon after, in June 2008, Samsung released the Samsung Instinct, a direct iPhone competitor. Since then, competition in the market has been quite stiff among the established players and new entrants. According to Cecere et al. (2014), the recent battle over patents and designs between Apple and Samsung is a clear indicator that smartphone makers are fiercely competing for leadership in the market.

Keller (2013) states that one of the most popular and potentially important marketing concepts to arise in the 1980s was brand equity. However, its emergence has had both a positive and negative impact on marketers. Keller suggests that on the positive side, brand equity has elevated the importance of the brand in the marketing strategy and provided a focus for managerial decisions and research activity. On the negative side, the concept has been defined in several different ways and for several other purposes, yet no common viewpoint has emerged about conceptualizing and measuring brand equity.

According to Andai (2016), brand equity is a set of components that add to, or subtract from, the value provided by a product or service to both the firm and its consumers. These assets include brand awareness, brand association, perceived quality, and brand loyalty. To manage brands properly, Andai emphasizes that marketers need to comprehend the value and aspects of their brands in terms of what makes them tick and what they are worth, and how they will measure and conduct the valuation of brand equity at consumer, product, and financial levels. Aaker (2010) highlighted that most brand equity studies were done for two main reasons: the financial aspect, and the other for strategy motivation and improvement of marketing productivity. Thus, marketers need to gain a better understanding of brand equity in terms of consumer behavior.

Consumer behavior is demonstrated when individuals search, purchase, use, and evaluate goods and services (Andai, 2016). The survival of firms largely relies on an in-depth understanding of the consumer. Given the current competitive business environment, manufacturers have been forced to produce goods with consumer needs in mind. They also consider the process involved in consumer decision-making. In the marketing context, the term 'consumer buying' means the purchasing act and activities that go along with the pre-purchase and post-purchase activities (Hawkins \& Mothersbaugh, 2010). More in-depth knowledge of consumer behavior helps marketers understand why and how consumers buy certain brands and how their environment shapes those decisions. In addition to the consumer decision-making process, a marketer also needs to understand the dynamics that affect the way individuals and groups buy goods and services. On this basis, this study seeks to find out the effect of brand equity on the consumer behavior of students at Veritas University.

The dimensions of brand equity often influence consumer preferences and intentions to purchase products and services (Andai 2016). Aaker (1996) and Keller (1998), Akhtar, Ulain, Siddiqi, Ashraf, and Latif (2016) identified dimensions of brand equity as brand awareness, brand association, perceived quality, and brand loyalty. Previous studies on brand equity (Akhtar et al. 2016; Christodoulides, Cadogan, \& Veloutsou, 2015; Chuma, 2017; Fouladivanda, Pashandi, 
Hooman, \& Khanmohammadi, 2013; Muhammad, Fazian, \& Ammar 2014; Nikhil, Shakiba \& Jalali, 2013; Sanket, \& Mallika, 2015; Tsai, Lo, \& Cheung, 2013; Zhang, Chatchai, \& Rizwan, 2014) focus on sectors like telecommunications, banking, hospitality, banking, construction, fastmoving consumer goods, etc. while ignoring the education sector. Does it mean that the concept of brand equity does not affect the education sector? Besides, most of the work on brand equity has been carried out in Europe and Asia, with very few in Africa.

Although there have been a series of research on consumer behavior (Orji, Oyenuga, \& Ahungwa, 2020), little has been conducted on how brand equity affects the subject matter in the education sector. This raises concern from researchers; for example, Boulding and Agyapong (2005) state: “... this raises an interesting research question: What is the relationship between brand equity and consumer behaviour?" Therefore, the present study's goal is to address this critical void in knowledge in this area.

The general objective of the study is to evaluate the brand equity of apple smartphones and consumer behaviour in Abuja. Therefore, the study will rest on the following specific objectives:

a. To determine the effect of brand awareness by consumers on apple smartphones in Abuja.

b. To know the effect of brand association by consumers on apple smartphones in Abuja.

c. To find out the effect of the perceived quality on apple smartphones by the consumers.

\section{Research Hypothesis}

H01: Brand awareness does not have any effect on consumer behavior among students of veritas university.

H02: Brand association does not have any effect on consumer behavior among students of veritas university.

H03: Brand loyalty does not have any effect on consumer behavior among students of veritas university.

\section{Literature Review}

During the last two decades, brand equity has been viewed from a variety of perspectives. The concept of brand equity began to be used widely in the 1980s by advertising practitioners. It was then popularized by Aaker (1991) through his bestselling book on the subject - "Managing Brand Equity" (1991). Other critical academic contributions have been developed throughout the years, advertising agencies have also continued to expand the cause and have developed their definitions and measurement systems.

David and Aaker (1991) consider that brand equity is "a set of brand assets and liabilities linked to a brand, its name, and symbol that add to or subtract from the value provided by a product or service to a firm/or to that firm's consumers." Although the assets and liabilities on which brand equity is based will differ from context to context, they can be usefully grouped into five categories: brand loyalty, brand name awareness, perceived brand quality, brand associations, and other proprietary brand assets.

Based on Aaker's model (2010), Ovidiu (2005) discussed that brand loyalty generates value by reducing marketing costs and leveraging trade. Loyal consumers expect the brand to be always available and entice others, advising them to use it. Retaining existing consumers is much less costly than attracting new ones, and even if there are low switching costs, there is significant inertia among consumers. It is also difficult for competitors to communicate with satisfied brand users because they have little motivation to learn about alternatives. Therefore, competitors may 
be discouraged from spending resources to attract satisfied and loyal consumers. Even if they do so, there is plenty of time to respond accordingly to that action.

Aaker (1996) explained that; brand awareness could provide the brand with a sense of the familiar and a signal of substance and commitment even at the recognition level. A typical brand is probably reliable and of reasonable quality. Awareness at the recall level further affects the choice by influencing what brands get considered and selected. The brand must first enter the consideration set before being on the purchase list.

Perceived quality provides a reason to buy and can also attract channel member interest, allow extensions, and support reinvestment (Chuma, 2017). A brand will have associated with it a perception of overall quality not necessarily based on detailed specifications. The quality associated with a brand can also be a substantial factor in differentiation and positioning. Building a strong, durable brand implies an above-average quality positioning or a minimum perceived quality when considering brands positioned as low market competitors. Brand associations may refer to persons, a "use context," a lifestyle or a personality. Associations can be critical factors in differentiating and positioning, creating a reason to buy to those potential consumers who are looking for specific associated physical or emotional features. Suppose a brand is well positioned upon a critical product attribute. In that case, a frontal assault by claiming superiority via that dimension will be a credibility failure, thus an association being a barrier to competitors. A strong association may also be the basis of a brand extension providing a significant competitive advantage in the targeted area.

Other proprietary brand assets refer to patents, trademarks, and channel relationships to provide a strong competitive advantage. A trademark will protect brand equity from competitors who might want to confuse consumers using a similar name, symbol, or package (Kotler \& Armstrong, 2014).

\section{Brand Awareness in Consumer Behavioiur}

According to Khaniwale (2015), consumer behaviour can be referred to as the combination of individuals' efforts before or while purchasing any product or service intended to fulfill an unmet need. Khaniwale further explains that buyer behaviour is the concept which answers what, why, how, when, and where an individual makes a purchase. As a result, the outcome of buyer behaviour is the buyer's decision. The consumer typically goes through five stages before the actual purchase.

Kotler and Armstrong (2014) point out that the consumer can skip a few stages during a routine purchase. That is, purchases of a habitual nature often lead directly to buying, and thus the second and third stages are skipped. However, when a consumer faces a new and complex purchase, for instance, where there is a change in price or availability, the buyer may reenter the full decision process and consider alternative brands. Whether complex or simple, the decisionmaking process starts with the recognition of a need.

Kotler and Armstrong (2014) suggest that internal or external stimuli can trigger a consumer's recognition of a need. Internal motivations are linked to a human's basic needs, such as thirst, that prompt the consumer to buy a water bottle. In contrast, external stimuli can be in the form of an advertisement that can get a potential consumer thinking about purchasing a new smartphone. It is at this stage when the consumer recognizes a distinct difference between their current and desired 
state. The need recognition process can occur naturally. However, marketers can often set it in motion by employing marketing tactics that create demand and encourage purchase.

After a need is recognized, the consumer engages with information searches to identify and evaluate alternative products and services. According to Khaniwale (2015), the possible sources of information include family, friends, personal observation, consumer reviews, salespeople, or mass media. However, millennials currently rely more so on the internet for information. The extent of the search will mostly depend on a consumer's drive and satisfaction got from the search (Kotler \& Armstrong, 2014). Despite consumers obtaining a large amount of their information from commercial sources controlled by marketers, Kotler and Armstrong believe that the most effective sources tend to be personal such as family or friends. As consumers obtain information, there is an increase of awareness towards available brands. Subsequently, this information helps consumers drop some brands when making the final selection of the evaluation. Lautiainen (2015) suggests that the evaluation of alternatives will vary among consumers and purchases. In the case of a habitual decision process, consumers often make little or no evaluation as their buying decision would typically be based on impulse and intuition. On the other hand, the consumers engaged in an extended problem-solving process may carefully evaluate several brands. Lautiainen further explains that the alternatives actively considered during the selection process are often influenced by factors such as financial costs, amount of information already obtained, perceived risk of possibly making the wrong choice, and the consumer's predisposition toward particular choices influenced by the individual's attitude towards choice behaviour.

After the evaluation of the alternatives, the consumer is then ready to make the actual purchase. Khaniwale (2015) pointed out that any intervention by marketers to simplify purchasing at this stage is often well received by the consumers, for example, by suggesting the best smartphone for a particular use through providing necessary product information on labels, advertising, and personal selling. Finally, after purchase, the consumer will then evaluate their satisfaction level. Lautiainen (2015) stated that if the consumer feels disappointed, their expectations are not met. However, when consumers' expectations exceed, this high level of satisfaction often translates into brand loyalty.

Brand awareness also refers to the degree of consumers' familiarity with a brand. Masika (2013) relates it to the brand's strength in memory as reflected by consumers' ability to identify the brand in different situations. Keller (2013) conceptualized brand awareness as comprising of brand recall and brand recognition. He argued that brand recognition might be more critical when product decisions are made in the store, and no one buys what they do not know. Masika pointed out that brand attitude and intention to purchase a product can only be developed through brand awareness.

Koniewski (2012) stated that employing brand awareness as a shopping guide is a strategy applied by consumers to save time and effort. When dealing with an unknown brand, they would devote themselves to comparing the products with other attributes, such as quality, packaging, and price. Brand awareness could be therefore interpreted as a cognitive simplification. Relying on brand awareness is a frequent tactical decision made when buying a product for the first time. When making subsequent purchases, the consumer focuses on the product's practical attributes, such as quality, functionality, taste, or fragrance. Koniewski noted that brand awareness has a more substantial impact on the subsequent purchasing choices if the product, once tried out, fulfilled the consumer's expectations. 
Aaker (2010) stated that there are various brand awareness levels, as presented in Figure 1. The lowest level is brand recognition and reflects familiarity, a manner of aided recall. The next level is brand recall, a manner of unaided recall and reflects an awareness of a brand when its product class is mentioned. The first named brand that comes to mind in an unaided recall test is called 'top-of-mind. That is, the brand has the most vital position in the respondent's mind.

Djerv and Malla (2012) believe that the brand's experience influences a consumer's top-ofmind awareness of a brand. Past experiences might include previous purchases, brand presence in various contact points such as advertising, media, press, social media, in-store experience, product placements, and what family and friends' perceptions of the brand are and their expressed opinions of it. Peter and Olson (2008) argued that spontaneous awareness is more desirable than prompted awareness, as it means the brand is top-of-mind. However, Masika (2013) claims that a good manager will realize that often it is not about being top-of-mind that drives purchase intentions, as a brand can be top-of-mind because it is actively disliked.

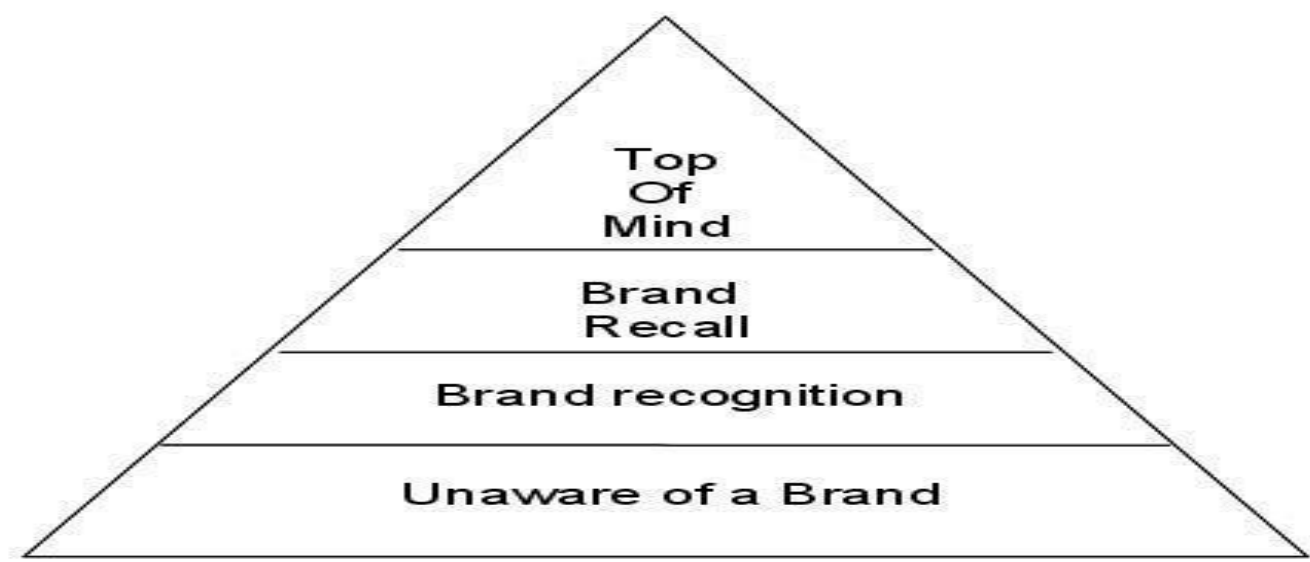

Figure 1. Awareness pyramid (Aaker, 2010)

To measure brand awareness effectively, Keller (2013) suggests that it is essential to know when and where most consumer decisions are made. Koniewski (2012) suggested that brand recognition measures decisions made at a point of purchase, where the brand, logo, and packaging are visible. However, if consumer decisions are made away from the point of purchase, then the brand recall measure becomes more critical.

The most basic recognition procedure is to ask the consumer which items they have previously seen or heard among several listed items. As for the brand recall, different brand recall measures depend on the type of signals given to the consumers: unaided recall and aided recall, which were described above. However, Koniewski warns that one should be aware of such a measure's limitations because consumers also perceive a brand through the prism of factors beyond the company's direct control, for example, recommendations by other consumers.

\section{Brand Association in Consumer Behaviour}

A brand association is anything connected to a brand by memory. Aaker (2010) believes that a brand name's underlying value is often based upon specific associations linked to it, whether positive or negative. According to Keller (2013), brand associations can be created by connecting the brand to a node or information in the memory that conveys meaning to consumers. The favorable brand values of consumers will affect their purchasing habits and brand preference. 
Cognitive psychologists believe that memory is extremely durable, so when information is stored, it decades very slowly (Djerv \& Malla, 2012). Still, being available in memory does not imply being accessible and retrieved without strong associations and retrieval cues (Aaker, 2010). Therefore, the larger the number of cues linked to a piece of information, the greater the likelihood that the information can be recalled (Mohan, 2014). Additionally, Mohan stated that brand associations could be influenced by information on objective attributes such as price and physical traits. Previous research has also shown that the differentiation, favorability, and strength of associations are important parts of brand knowledge. This, in turn, is an essential source of consumer-based brand equity (Keller, 2013).

\section{Brand Loyalty in Consumer Behaviour}

Aaker (2010) defines brand loyalty as the attachment that a consumer has to a brand. It consists of both attitudes and actual behaviours toward a brand, and that both must be measured. Attitudinal measures are concerned with consumers' overall feelings about the product and the brand, that is, evaluation and their purchase intentions (Schiffman et al., 2010). Schiffman further elaborated that behavioural measures are based on observable and factual behaviours regarding the brand, such as quantity purchased, purchase frequency, and repeat purchase. Behavioural scientists who favor the theory of instrumental conditioning believe that brand loyalty results from an initial product trial reinforced through satisfaction, leading to repeat purchase.

On the other hand, Masika (2013) noted that cognitive researchers emphasize the role of mental processes in building brand loyalty. They believe that consumers engage in extensive problem-solving behaviour involving brand and attribute comparisons, leading to a strong brand preference and repetition in purchase behaviour. Therefore, brand loyalty is the synergy amongst attitudinal components such as perceived product superiority, consumer satisfaction, and purchase behaviour.

However, according to Aure and Nervik (2014), behavioural definitions such as purchase frequency or proportion of total purchases lack precision because they do not distinguish between a real brand loyal buyer who is intentionally faithful and the ingenuine brand loyal buyer who repeats a brand purchase based on mere habit or because it is the only one available at the store. Often consumers buy from a mix of brands within their acceptable range. The greater the number of acceptable brands in a specific product category, the less likely the consumer is to be brand loyal to a particular brand. Conversely, products having a few competitors in the marketplace and those purchased with great frequency, are likely to have greater brand loyalty (Fouladivanda et al., 2013). Thus, a more favorable attitude toward a brand compared to potential alternatives, together with repeat patronage, are seen as the requisite components of consumer loyalty. Behavioural brand loyalty leads to higher market share, and attitudinal loyalty often enables the marketer to change a price for the brand relative to the competition.

Despite numerous literature on brand loyalty, Burton (2012) noted that the comprehension of the phenomenon remains lacking as the subtle distinction concerning the essential thought of commitment has not been expressly articulated nor appreciated. Burton (2012) suggests that the uninspired, non-diagnostic, and sometimes conflicting operationalization of the construct is at least partially to blame for the reactions of those who debate either the very existence of brand loyalty in the consumer marketplace or its theoretical significance in the marketing field. The understanding of the processes governing brand loyalty also suffers significant shortcomings. Though researchers identify brand loyalty as a function of psychological decision-making and 
evaluative processes exhibited over time, little insight into the process condition has been obtained - theories of attitude formation primarily from cognitive psychology guide most of the explanations drawn for loyalty.

An integrated conceptual framework by Schiffman et al. (2010) views consumer loyalty as the function of three groups of factors, namely: the personal degree of risk aversion or variety seeking, the brand's reputation and availability of substitute brands, and social group influences and peers' recommendations. These influences produce four types of loyalty. Firstly, no loyalty: no purchase at all and no cognitive attachment to the brand. Secondly, covetous loyalty: no purchase but strong attachment and predisposition toward the brand that was developed from the person's social environment. Thirdly, inertia loyalty: purchasing the brand because of habit and convenience but without any emotional attachment. Finally, premium loyalty: high attachment to the brand and high repeat purchase.

In summary, loyalty can be seen to be formed through brand trust, commitment, satisfaction, perceived value, image, association, and quality. Therefore, when a firm establishes loyalty amongst its consumers, it adds value to the brand and creates strong brand affiliation, reduces marketing expenditure, and influences other potential consumers through positive word-of-mouth (Andai, 2016).

\section{Method}

\section{Research Design and Sample}

A descriptive research design was employed to conduct this research to determine the relationship between brand equity (the independent variable) and consumer behaviour (the dependent variable) within Veritas University. The population of interest in this study is the student body of Veritas University Abuja. All students of veritas university Abuja at the time of the study in 2020, based on the data from the 2019/2020 academic session, stand at 2,320 students. The formula used to arrive at the above sample size is as follows:

$n=\frac{N}{1+N(e)^{2}}$

Yamane (1967)

$\mathrm{n}=$ Sample size

$\mathrm{N}=$ Population size $-2,230$

$\mathrm{e}=$ Degree of accuracy -0.05

by applying the formula, the following solution was derived:

$n=\frac{2320}{1+2320(0.05)^{2}}$

$n=\frac{2320}{1+2320(0.0025)}$

$n=\frac{2320}{1+5.8}$

$n=\frac{2320}{6.8}$

$\therefore n=341$ 


\section{Data Collection}

A self-administered survey was used to collect the primary data of this research, whereas respondents completed the survey independently. This is the preferred method because it is low cost in nature and very convenient to administer, in the sense that one does not need to have a face-to-face meeting or interview with the respondents to gather information. The research questionnaire, which was adapted from the works of Chuma (2017), Rio et al. (2001), and Qaisar and Ali (2018), consists of two sections. Section one contains structured closed-ended questions and addressed respondents' demographic characteristics, whereas section two addressed the effect of brand equity dimensions on consumer buyer behaviour of smartphones. In this section, a fivepoint Likert scale is used to collect information, enabling respondents to indicate their level of agreement, neutrality, or disagreement with the questions asked.

\section{Data Analysis}

Data collected were coded, edited, and analysed using Statistical Package for Social Science (SPSS). Descriptive statistics were used to analyse data with the use of frequencies and percentages. Overall mean scores and standard deviations of brand equity dimensions and consumer buyer behaviour were computed and evaluated. Inferential statistics were conducted using regression and correlation analysis to determine the relationship between the dependent and independent variables.

\section{Results}

\section{Response Rate and Demographic Profile}

A random sampling method was applied to select 341 respondents from the student population of Veritas University. In all these, 341 students were contacted and surveyed. However, two hundred and thirty-eight responses were received, representing a total response rate of $69.79 \%$. Table 1 describes the response rate of respondents. A total of 238 students responded, while the nonrespondents were 103.

Table 1

Response Rate

\begin{tabular}{lcc}
\hline Response Category & Frequency & Percentage \\
\hline Response & 238 & 69.79 \\
Non-Response & 103 & 30.21 \\
Total & 341 & 100.00 \\
\hline
\end{tabular}

The demographic information considered in the study was respondents' Gender, Age, College, smartphone Use, smartphone brand Type, Average income per month. The results show that the number of male and female are 71 and 167 respectively. Most of the students are between the ages of 20 and 24, while 221 own smartphones. The results are summarized in Table 2. 
Table 2

Characteristics of the Respondent

\begin{tabular}{|c|c|c|}
\hline Characteristic & Frequency & Percent \\
\hline \multicolumn{3}{|l|}{ Gender } \\
\hline Male & 71 & 29.83 \\
\hline Female & 167 & 70.17 \\
\hline Total & 238 & 100.00 \\
\hline \multicolumn{3}{|l|}{ Age } \\
\hline $15-19$ years & 67 & 28.15 \\
\hline 20-24 years & 113 & 47.48 \\
\hline $25-29$ years & 39 & 16.39 \\
\hline 30 and above & 19 & 7.98 \\
\hline Total & 238 & 100.00 \\
\hline \multicolumn{3}{|l|}{ Educational Qualification } \\
\hline Natural \& Applied Sciences & 37 & 15.55 \\
\hline Management Sciences & 85 & 35.71 \\
\hline Humanities & 38 & 15.97 \\
\hline Social Sciences & 43 & 18.07 \\
\hline Education & 19 & 7.98 \\
\hline Post Graduate Studies & 16 & 6.72 \\
\hline Total & 238 & 100.00 \\
\hline \multicolumn{3}{|l|}{ Smartphone Ownership } \\
\hline Yes & 221 & 92.86 \\
\hline No & 17 & 7.14 \\
\hline Total & 238 & 100.00 \\
\hline \multicolumn{3}{|l|}{ Smartphone Brand } \\
\hline Apple & 11 & 4.98 \\
\hline Samsung & 44 & 19.91 \\
\hline Techno & 66 & 29.86 \\
\hline LG & 22 & 9.95 \\
\hline Infinix & 57 & 25.79 \\
\hline Nokia (Others) & 21 & 9.50 \\
\hline Total & 221 & 100.00 \\
\hline
\end{tabular}

\section{Descriptive Statistic for Brand Awareness}

As shown in Table 3, the majority of the respondent "strongly agreed" that they would only buy a smartphone from a brand that is well known to them, $M=4.52, S D=3.20$. Contrary, most of the respondents "strongly disagreed" that they would be willing to buy a smartphone from a brand they do not know about, $M=1.91, S D=2.46$. Furthermore, most of the respondents "disagreed" that they typically buy a smartphone from a brand that they can quickly recognize among competing brands, $M=4.08, S D=2.45$. Moreover, most of the respondents "disagreed" that before purchase, they could promptly recall the symbol/logo of their current smartphone, $M$ $=4.03, S D=2.40$. Besides, most of the respondents "disagreed" that if they could buy a new smartphone today, they would most likely purchase the brand that first comes to mind, $M=4.17$, $S D=2.55$. 
Table 3

Descriptive Statistic for Brand Awareness

\begin{tabular}{lcc}
\hline Brand awareness & $M$ & $S D$ \\
\hline I would only buy a smartphone from a brand that is well known to me. & 4.52 & 3.20 \\
$\begin{array}{l}\text { I would be willing to buy a smartphone from a brand I have no knowledge } \\
\text { about. }\end{array}$ & 1.91 & 2.46 \\
$\begin{array}{l}\text { I typically buy a smartphone from a brand that I can quickly recognize among } \\
\text { competing brands. }\end{array}$ & 4.08 & 2.45 \\
$\begin{array}{l}\text { Before purchase, I could quickly recall the symbol/logo of my current } \\
\text { smartphone. }\end{array}$ & 4.03 & 2.40 \\
If I could buy a new smartphone today, I would most likely purchase the \\
brand that first comes to mind.
\end{tabular}

\section{Descriptive Statistic for Brand Association}

The study sought to determine the frequency of the rate of perception of brand association. Using a 5-point Likert scale where 1.00-1.499 strongly disagreed; 1.50 - 2.499 disagreed; 2.50 3.499 was neutral; 3.50 - 4.499 agreed, and 4.50 -5.00 strongly agreed, the respondents were asked to indicate their level of agreement with brand association. The results presented in Table 4 show that most of the respondents "strongly agreed" that they would only consider buying a smartphone from a credible brand, $M=4.51, S D=3.17$. Furthermore, most of the respondents "strongly agreed" that they are more likely to buy a smartphone from a highly reliable brand and strives to continuously improve the performance qualities of its devices, with $M=4.53, S D=$ 3.22. Likewise, most of the respondents "strongly agreed" that they tend to buy smartphones from brands that they feel are appealing and favorable, $M=4.52, S D=3.20$.

Table 4

Descriptive Statistic for Brand Association

\begin{tabular}{lcc}
\hline Brand association & $M$ & $S D$ \\
\hline I would only consider buying a smartphone from a credible brand. & 4.51 & 3.17 \\
I am more likely to buy a smartphone from a brand that is highly reliable and & 4.53 & 3.22 \\
strives to continuously improve the performance qualities of its devices. & 4.52 \\
I tend to buy smartphones from brands that I feel are appealing and favorable. & 4.57 \\
I am more likely to buy a smartphone from a brand that reflects my individual & 3.20 \\
personality (e.g., practical, flamboyant). & 4.73 \\
I am more likely to buy a smartphone that is in fashion. & 3.29 \\
\hline
\end{tabular}

\section{Descriptive Statistic for Brand Loyalty}

As shown in Table 5, most of the respondents "strongly agreed" that they are more likely to buy a smartphone from a brand that they believe in offering value for money, $M=4.52, S D=3.19$. Additionally, most of the respondents "strongly agreed" that they are more likely to buy a smartphone from a brand that they believe does not disappoint consumers, $M=4.58, S D=3.30$. Furthermore, most of the respondents "strongly agreed" that they are more likely to buy a smartphone from a brand that they would be willing to recommend to their friends, $M=4.52, S D$ $=3.21$. Likewise, most of the respondents "strongly agreed" that they are more likely to buy a smartphone from a brand that they take a keen interest in, with a mean of 4.61 and a standard deviation of 3.34. Additionally, the majority of the respondent "strongly agreed" that they are more likely to buy a smartphone from a brand that is typically my first choice, $M=4.64, S D=$ 3.39. Lastly, most of the respondents "strongly agreed" that they are more likely to buy a smartphone from a brand that they take a keen interest in, $M=4.50, S D=3.17$. 
Table 5

Descriptive Statistic for Brand Loyalty

\begin{tabular}{lcc}
\hline Brand loyalty & $M D$ & \multicolumn{1}{c}{$S$} \\
\hline I am more likely to buy a smartphone from a brand that I believe to offer value for & 3.52 \\
money. & 4.58 \\
I am more likely to buy a smartphone from a brand that I believe does not disappoint & 4.52 \\
consumers. & 3.30 \\
I am more likely to buy a smartphone from a brand that I would be willing to & 3.61 \\
recommend to my friends. & 4.64 \\
I am more likely to buy a smartphone from a brand that I take a keen interest in. & 4.50 \\
I am more likely to buy a smartphone from a brand that is typically my first choice. & 3.34 \\
I am more likely to buy a smartphone from a brand that I take a keen interest in. & 3.39 \\
\hline
\end{tabular}

\section{Descriptive Statistic for Consumer Behaviour}

As presented in Table 6, most of the respondents "agreed" that they would be willing to pay a premium price for a smartphone from my brand of choice, $M=3.90, S D=2.31$. Furthermore, most of the respondents "agreed" that they would be willing to recommend to others a smartphone from their brand of choice, $M=4.00, S D=2.44$. Lastly, most of the respondents "agreed" that if their brand of choice was to sell products other than smartphones, they would probably buy them, $M=3.60, S D=2.01$.

Table 6

Descriptive Statistic for Consumer Behaviour

\begin{tabular}{lc}
\hline Consumer behaviour & $M$ \\
\hline $\begin{array}{l}\text { I would be willing to pay a premium price for a smartphone from my brand } \\
\text { of choice. }\end{array}$ & 3.90 \\
$\begin{array}{l}\text { I would be willing to recommend to others a smartphone from my brand of } \\
\text { choice. }\end{array}$ & 4.00 \\
$\begin{array}{l}\text { If my brand of choice was to sell products other than smartphones, I would } \\
\text { probably buy them. }\end{array}$ & 3.60 \\
\hline
\end{tabular}

\section{Correlation Matrix}

This study established a positive relationship between the dependent variable, consumer behavior, and the independent variables, brand awareness, brand association, and brand loyalty, as displayed in Table 7. First, the significant Pearson's correlation coefficient between consumer behavior and brand loyalty was .49 , which means that the two variables move in the same direction. This implies that an increase in brand loyalty increases consumer behavior. Consumer behavior and brand association showed a significant Pearson's correlation coefficient of .46, which means an increase in brand association increases consumer behavior. Furthermore, there is a strong positive and significant relationship between brand awareness and consumer behavior, with Pearson's correlation coefficient of .53. This implies that an increase in brand awareness leads to a rise in consumer behavior.

Table 7

Correlations Matrix

\begin{tabular}{|c|c|c|c|c|c|}
\hline & & BLO & BAS & BAW & $\overline{\mathrm{CB}}$ \\
\hline BLO & $\begin{array}{l}\text { Pearson Correlation } \\
\text { Sig. (2-tailed) }\end{array}$ & 1 & & & \\
\hline BAS & $\begin{array}{l}\text { Pearson Correlation } \\
\text { Sig. (2-tailed) }\end{array}$ & $\begin{array}{l}.42^{* *} \\
.00\end{array}$ & 1 & & \\
\hline BAW & $\begin{array}{l}\text { Pearson Correlation } \\
\text { Sig. (2-tailed) }\end{array}$ & $\begin{array}{l}.45^{* *} \\
.00\end{array}$ & $\begin{array}{l}.56^{* *} \\
.00\end{array}$ & 1 & \\
\hline $\mathrm{CB}$ & $\begin{array}{l}\text { Pearson Correlation } \\
\text { Sig. (2-tailed) }\end{array}$ & $\begin{array}{l}.49^{* *} \\
.00\end{array}$ & $\begin{array}{l}.46^{* *} \\
.00\end{array}$ & $\begin{array}{l}.53^{* *} \\
.00\end{array}$ & 1 \\
\hline & $\mathrm{N}$ & 221 & 221 & 221 & 221 \\
\hline
\end{tabular}

**Correlation is significant at the .01 level (2-tailed), $\mathrm{BAW}=$ brand awareness, $\mathrm{BAS}=$ brand association, $\mathrm{BLO}=\mathrm{brand}$ loyalty, $\mathrm{CB}=\mathrm{Consumer}$ behavior 


\section{Coefficients}

From Table 8 , it can be deduced that brand loyalty $(\beta=.39)$, brand association $(\beta=.15)$, and brand awareness $(\beta=.29)$ are significant. This indicates that the dependent variable, consumer behavior, would change by a corresponding number of standard deviations when brand awareness or brand association, or brand loyalty change by one standard deviation. These findings imply that if brand loyalty changed by one (1) unit, consumer behavior would change by .39 units if other factors remain fixed. The findings also imply that if brand association changed by one (1) unit, consumer behavior would change by .15 units if other factors remain fixed. Lastly, the findings imply that if brand awareness changed by one (1) unit, consumer behavior would change by .29 units if other factors remain fixed. The null hypotheses 1, 2, and 3 were therefore rejected since brand awareness, brand association, and brand loyalty significantly influenced consumer behavior. Thus, the researcher opted for alternative hypotheses, which conforms with (Ashraf, Sulehri, \& Abbas 2018; Chinomona \& Maziriri 2017; Masika, 2013.

Table 8

Coefficients $^{a}$ Reports

\begin{tabular}{llccccc}
\hline & & \multicolumn{2}{c}{ Unstandardized Coefficients } & \multicolumn{3}{c}{ Unstandardized Coefficients } \\
\cline { 3 - 7 } Model & & $\mathrm{B}$ & Std. Error & $\beta$ & $t$ & $p$ \\
\hline 1 & (Constant) & 1.28 & .24 & & 5.33 & .00 \\
& Brand loyalty & .39 & .08 & .28 & 4.54 & .00 \\
& Brand association & .15 & .05 & .17 & 2.59 & .01 \\
& Brand awareness & .29 & .06 & .31 & 4.59 & .00 \\
\hline
\end{tabular}

a. Dependent Variable: Consumer behavior

\section{Discussion}

The general objective of the study was to determine the effect of Apple Smartphones brand equity on consumer behaviour among students of Veritas University. Firstly, this study showed that brand awareness had a significant positive effect on consumer behaviour among students of Veritas University. This result implies that brand awareness is recognized as an essential factor that can influence consumer behaviour. This is because brand recognition may be more important when product decisions are made in the store, and no one buys what they do not know. Awareness at the recall level further affects the choice by influencing what brands get considered and selected. The brand must first enter the consideration set before being on the purchase list. This finding agrees with many researchers who found brand awareness as an element that plays a vital role in a consumer's choice of brand. For example, the study conducted by Masika (2013) found that brand awareness had the most powerful influence on consumers' purchase decisions. Lin and Chang (2003) examined the importance of brand awareness in consumers' decisionmaking process and found out that brand awareness was a primary factor in consumer buying behaviour.

Secondly, the brand association has a significant positive effect on consumer behaviour among students of Veritas University. This implies that brand association is strongly demanded in increasing consumer behavior. The brand association describes any memory or perception that a consumer may have in connection with the brand. The result shows that a positive consumerbased brand association has many advantages like long-term revenues, consumers' willingness to seek out new channels of distribution, firms' ability to command higher prices, and marketing communications effectiveness. Associations can be critical factors in differentiating and positioning, creating a reason to buy to those potential consumers looking for specific associated 
physical, emotional features. A strong association may also be the basis of a brand extension providing a significant competitive advantage in the targeted area. This finding is similar to the study of Chinomona and Maziriri (2017), who assessed the influence of brand awareness, brand association, and product quality on brand loyalty and repurchase intention among male consumers of cosmetic brands in South Africa. The findings indicated that brand awareness has a positive and significant influence on brand loyalty. The brand association has a positive and insignificant impact on brand loyalty. Product quality has a positive and significant effect on brand loyalty, and brand loyalty exerts a positive and significant influence on purchase intention. Likewise, Ashraf, Sulehri, and Abbas (2018) examined the impact of the brand association dimensions on the consumer responses. Their results revealed a positive relationship between the brand association dimensions on the consumer buying behavior. The brand association functions are the guarantee, social identification, personal identification, and status that positively impact the recommendation, extension of purchase from the same brand, and price premium. The results of this study may help the researcher who is trying to find the relation between the brand association dimensions and consumer behavior towards the brand.

Thirdly, the result revealed that brand loyalty has a significant positive effect on consumer behaviour among Veritas University students. This result implies that loyal consumers expect the brand to be always available and entice others advising them to use it. Retaining existing consumers is much less costly than attracting new ones, and even if there are low switching costs, there is significant inertia among consumers. It is also difficult for competitors to communicate with satisfied brand users because they have little motivation to learn about alternatives. Therefore, competitors may be discouraged from spending resources to attract satisfied and loyal consumers. Even if they do so, there is plenty of time to respond accordingly to that action. This finding is in agreement with the study of Qaisar and Ali (2018), who examined the impact of brand loyalty on the consumer buying behavior of people who live in big cities but belong to small cities. The findings showed that all hypotheses are supported and found that brand loyalty greatly affects consumer buying behavior. Brand loyalty has some dimensions: product price, product quality, brand image, promotion, and product design. Also, Kothari and Maindargi (2019) examined the effect of brand loyalty on each dimension of consumer buying behavior related to retail trade in Solapur City. They found that in the retail industry as per the grocery trade is concerned, consumers are still giving preference to prize and test, whereas Packaging flavor and appearance do not play an important role. Most consumers know brands available in markets and do not show a willingness to switch their brand.

\section{Conclusion and Recommendation}

The findings of the study indicated that the independent variables (brand awareness; brand association, and brand loyalty) had a positive effect on consumer behaviour among students of Veritas University. It was concluded that when consumers are attached and loyal to a brand, they are likely to make repeat purchases, and this only happens when the relationship between the brand and the user is very in-depth and has an emotional connection with the mobile brand. Thus, it has become crucial for marketers that they should highlight the features and functional capabilities of the mobile while presenting their brands to their target market and define what the brands stand for and how it affects the relationship with the consumers. In short, a step-by-step process should be taken from defining as who the brand is (brand awareness) to highlighting its points of differentiation and user profile (brand performance and brand association) by taking 
both the functional route (brand quality) and emotional route (brand feelings). Thus, the consumers can evaluate it positively and form a bond that will result in everlasting and unbreakable bond (brand loyalty) that moulds and influences their purchase decision.

The findings also revealed that brand awareness has a positive and significant effect on Veritas University students' consumer behavior. On the practitioners 'side, marketers or brand managers can benefit from the implications of these findings. For example, given the robust relationship between brand loyalty and consumer behaviour, it is recommended that brand managers pay attention to high-quality products to enhance brand awareness campaigns for their products and promotions for consumers to be associated with brands. As a result, consumers to be loyal and to repurchase cosmetic brands. The consumers can also spread through word of mouth to other male friends, brothers, or fathers within their families, thereby boosting their production and profits.

The findings further revealed that brand association has a positive and significant effect on consumer behaviour among Veritas University students. The study recommended that firms interested in extending consumer behaviour to repurchase their product categories should pay special attention to the brand associations linked to the functions of guarantee, social identification, and status. Regarding firms wishing to apply a price premium to their products, it would be essential for them to promote associations related to guarantee and social identification functions. Concerning the ways of stimulating the users of a brand to recommend it to others, it would be fitting to resort to the functions of guarantee and personal identification. Therefore, the development of these functions entails the firm generating positive communications towards the brand. As we argued above, the brand's recommendation seems to be determined by the consumers' perceptions of it rather than by the brand's image and social prestige.

Finally, the finding from the study revealed that brand loyalty has a positive and significant effect on consumer behaviour among students of Veritas University. Based on the results, it is recommended that manufacturers devote their great attention and consideration towards the effect of a brand's image because it has a large effect on consumers' attitudes and thus leads to brand loyalty. Brands must introduce some schemes to their consumers through which they offer some incentive to the client, and the client stays faithful to the association. Pricing an item and its accessibility strongly affect consumer buying behavior, so these elements must be considered. Low prices with good quality attract consumers, and switching behavior from one brand to another brand declines. The marketing managers in firms should pay very close attention to the consumer's needs and demands prevailing in the market. The product which is offered to the consumers should meet the needs and demands of the consumers.

\section{References}

Aaker, D. A. (1991). Managing brand equity: Capitalizing on the value of a brand name. New York: The Free Press.

Aaker, D. A. (1996). Measuring Brand equity across products and markets. California Management Review, 38(3), 102-120.

Aaker, D.A. (1996). Building Strong Brands, The Free Press, New York.

Aaker, D. A. (2010). Building strong brands. New York, NY: Free Press.

Akhtar, N., Ul-ain, Q., Siddiqi, U., Ashraf, A., \& Latif, M. (2016). Impact of a brand equity on consumer purchase decision in L'Oréal skincare products. Journal of International Review of Management and Business Research, 5(2), 808-816. 
Andai, J. (2016). Influence of brand equity on consumer purchase choices among pay TV subscribers in Nairobi, Kenya (Unpublished MBA project). University of Nairobi.

Ashraf, M., Sulehri, H. A., \& Abbas, S. (2018). Impact of Brand Association on Consumer Buying Behavior in Foot Ware Industry: The Case of Punjab, Pakistan. International Journal of Academic Research in Business and Social Sciences, 8(3), 91-102.

Aure, K. G., \& Nervik, K. D. (2014). Building strong brands: A quantitative study of brand equity (Unpublished MBA project). Aalesund University College.

Boulding R., \& Agyapong, G. K. (2005). Analysis of the antecedents of customer loyalty of telecommunication industry in Ghana: The case of Vodafone (Ghana). International Business Research, 4(1), 229-240.

Burton, H. W. (2012). Store loyalty: A relationship perspective. Journal of Asia-Pacific Advances in Consumer Research, 10(3), 293-295.

Cecere, G., Corrocher, N., \& Battaglia, R. D. (2014). Innovation and competition in the smartphone industry: Is there a dominant design? Journal of Telecommunications Policy, 39(4), 162-175.

Chen, T. Y., Yeh, T. L., \& Jheng, W. S. (2013). Factors influencing brand association. African Journal of Business Management, 7(19), 1914-1926.

Chinomona, R., \& Maziriri, E. T. (2017). The influence of brand awareness, brand association and product quality on brand loyalty and repurchase intention: a case of male consumers for cosmetic brands in South Africa. Journal of Business and Retail Management Research, 12(1), 50-54.

Christodoulides, G., Cadogan, J. W., \& Veloutsou, C. (2015). Consumer-based brand equity measurement: lessons learned from an international study. International Marketing Review, 32(3/4), 307-328.

Chuma, D. (2017). Measuring customer-based brand equity of Samsung mobile phones among Generation (Unpublished doctoral dissertation). University of Wits.

Churchill, G. A., Brown, T. J., \& Suter, T. A. (2010). Basic marketing research (7th ed). China: Cengage Learning.

Djerv, S., \& Malla, Z. (2012). A qualitative study of the drivers of brand preferences in the Swedish smartphone market (Unpublished MBA project). University of Uppsala.

Fouladivanda, F., Pashandi, M. A., Hooman, A., \& Khanmohammadi, Z. (2013). The effect of brand equity on consumer buying behavior in term of FMCG in Iran. Interdisciplinary Journal of Contemporary Research in Business, 4(9), 945-957.

Hawkins, D. L., \& Mothersbaugh, D. L. (2010). Consumer buyer behavior: Building market strategy (11th ed.). New York, NY: McGraw Hill.

Keller, K. (2013). Strategic brand management: Building, measuring and managing brand equity. Upper Saddle River, NJ: Pearson.

Keller, K.L. (1998). Strategic brand management: Building, measuring and managing brand equity. New Jersey: Prentice Hall.

Khaniwale, M. (2015). Consumer buying behavior. Journal of Innovation and Scientific Research, 14(2), 278-286.

Koniewski, M. (2012). Brand awareness and consumer loyalty (Unpublished MBA project). University of Sweden.

Kothari, P. P., \& Maindargi, S. C. (2019). Impact of brand loyalty on consumer behavior towards grocery trade: With special reference to solapur city. International Journal of Science Technology and Engineering, 5(7), 7-14.

Kotler, P., \& Armstrong, G. (2014). Principles of marketing. New York, NY: Pearson.

Lautiainen, T. (2015). Factors affecting consumer's buyer decision in the selection of a coffee brand (Unpublished MBA project). Saimaa University of Applied Sciences.

Masika, C. (2013). The influence of mobile marketing on brand equity; A case study of Safaricom Limited (Unpublished MBA project). University of Nairobi.

Mohan, A. (2014). Consumer behavior toward smartphone industry in Indian market (Unpublished MBA project). Dublin Business School.

Mugenda, O. N., \& Mugenda, A. G. (1999). Research methods: A quantitative and qualitative approach. Nairobi: ACTS press.

Muhammad, R., Fazian, A., \& Ammar, V. (2014). The comparative analysis of the factors affecting brand loyalty towards Samsung products. Journal of Sociological Research, 5(1), 23-27.

Nikhil, M., Sanket, K., \& Mallika, B. (2015). impact of brand loyalty of existing restaurant on newly opened restaurants in Chandigarh. International Journal of Advanced Research in Management and Social Sciences, 4(12), 110-115.

Orji M. G., Oyenuga M. O., \& Ahungwa A. I. (2020). Effects of sales promotion on consumer buying behaviour of food seasoning among Nigerian Households: A case study of Nestle Maggi Naijapot. Budapest International Research and Critics Institute Journal, 3(1),134-139.

Ovidiu, M. (2005). The concept of brand equity-a comparative approach. Retrieved from https://mpra.ub.unimuenchen.de/32013/ 
Peter, J. P., \& Olson, J. C. (2008). Consumer behavior and marketing strategy. New York, NY: McGraw Hill.

Qaisar, H. M., \& Ali, M. (2018). Impact of brand loyalty on consumer buying behavior in Punjab University's Hostels. Singaporean Journal of Business, Economics and Management Studies, 51(6086), 1-11.

Sarwar, M., \& Soomro, T. R. (2013). Impact of smartphones on society. European Journal of Scientific Research, 98(2), 216226.

Schiffman, L. G., Kanuk, L. L., \& Wisenblit, J. (2010). Consumer buyer behavior (10th ed.). Upper Saddle River, NJ: Pearson.

Shakiba, G. J. A., \& Jalali, S. H. (2013). Conceptualization of customer-based brand equity in financial service sector. Studies in Business and Economics, 8(1),123-133.

Tsai, H., Lo, A., \& Cheung, C. (2013). Measuring customer-based casino brand equity and its consequences. Journal of Travel and Tourism Marketing, 30(8), 806-824.

Yamane, T. (1967). Statistics: An introductory analysis (2nd ed). New York: Harper and Row.

Zhang, J., Chatchai, P., \& Rizwan, S. (2014). The relationship of brand equity dimensions: A case study of Samsung brand in Thailand. European Journal of Business and Management, 10(3), 25-30 